\title{
Effectiveness of Strychnos ligustrina BI. extract as feed supplementation to increase immune system of Nile Tilapia (Oreochromis niloticus) wich againts Streptococcus agalactiae
}

\author{
Anis Zubaidah ${ }^{1 *}$, Kuny Rizki Faidah ${ }^{1}$, Sri Samsundari ${ }^{1}$ \\ Fisheries Department, Faculty of Agriculture and Animal Science, University of Muhammadiyah \\ Malang, Indonesia. \\ *aniszubaidah@umm.ac.id
}

https://doi.org/10.22219/ijota.v1i1.6082

\begin{abstract}
One of the problems of intensive cultivation of tilapia is the attack of Streptococcosis disease caused by Streptococcus agalactiae bacteria. To prevent it is necessary to prevent the use of natural antibiotics that is Strychnine bush extract. Research with the title Effectiveness of Strychnine bush Extract (Strychnos ligustrina BI.) On Feed against Tilapia Resistant Immune Response (Oreochromis niloticus) Infected with Streptococcus agalactiae bacteria was carried out at Fishery Laboratory of the Faculty of Agriculture and Animal Husbandry of University of Muhammadiyah Malang on 25 August to 16 September 2017. The material used is extract of songga wood and fish tilapia size $9-12 \mathrm{~cm}$ as many 80 tails divided into 20 aquariums, where each aquarium contains 4 tails and Streptococcus agalactiae bacteria. The purpose of this research is to know the effect of giving Strychnine bush extract to the dosage to get the dose of songga extract of wood which is effective to give the best influence to the nile tilapia (Oreochromis niloticus) immune response covering hematocrit level, leukocrit level, leukocyte count and phagocytosis activity. The method used in this research is the experimental method using Completely Randomized Design (RAL), then the data is analyzed by using ANAVA. In this research, there were five treatments with various dosages, namely treatment $(\mathrm{K}: 0 \%),(\mathrm{A}: 5 \%),(\mathrm{B}: 10 \%)$, (C: $15 \%)$ and (D: $20 \%$ ), each treatment was repeated four times. The main parameters used are hematocrit level, leukocrit level, leukocyte count and phagocytosis activity. As a supporting parameter is water quality and MIC (Minimum Inhibitation Concentration) test. The results showed that dosage of Strychnine bush extract did not affect the level of hematocrit and leukocrit level, but significant effect on leukocyte count with the highest value at treatment B with $10 \%$ dose is $11,9 \times 105$ cell / mm3. Giving extract also significant effect on phagocytosis activity with the highest phagocytosis value at treatment B with dose of $10 \%$ that is $32 \%$.
\end{abstract}

Keywords: Strychnine bush, Hematocrit, Leukocrit, Leucocytes and Phagocytosis

\section{Introduction.}

Tilapia (Oreochromis niloticus) is a freshwater fish that is widely cultivated in Indonesia and is a cultivated fish that became one of the exports. Tilapia also has high economic value, has a high protein content and advantages develop rapidly. Nutritional content of tilapia is $16-24 \%$ protein, fat content ranges from $0.2-2.2 \%$ and contains carbohydrates, minerals, and vitamins. The ultivation 
the process of cultivation of tilapia fish often there is one of the problems of disease outbreak. Epidemic attacks occur as a result of disturbance of balance and interaction between fish, unfavorable environments of fish and the development of disease-causing pathogens. Outbreaks of diseases that attack freshwater fish, especially tilapia are bacterial diseases of Stretococcosis caused by Streptococcus agalactiae bacteria. Outbreaks of the bacterium $S$. agalactiae are acute and can cause high mortality up to $100 \%$ in cultivated fish.

Prevention of diseases in fish culture especially bacterial disease Streptococcosis, especially in tilapia commodities still use chemicals such as antibiotics, antimicrobial drugs and disinfectants. The use of chemicals for the treatment of tilapia disease is currently limited because it can have adverse effects on the environment and fish therefore need to find an alternative to prevent disease problems without the use of antibiotics and other chemicals. The use of natural antibiotics is one good alternative in dealing with the problem of bacterial diseases. Songga wood ( $S$. ligustrina) is a natural ingredient with antibiotic content that is used as a malaria drug by most people of Bima, West Nusa Tenggara and Bali, in addition songga wood is also used to treat diabetes and high blood. Sarmento et al. (2015) research suggests that songga wood (S. ligustrina) Has antimicrobial, antioxidant, and anticancer activity.

Songga wood is known in leaf, wood, bark, and root contain phenolic compound that is compound of alkaloid group, flavonoid, phenol, and tannin and triterpenoid. The content of phenolic compounds is known to show antifungi, insecticide, bactericidal, antiviral activity and inhibit the action of enzymes. Based on the above background then this research is very important to do to know the effectiveness of songga wood extract to the immune response in tilapia. Tilapia immune response can be known through observation of non-specific immune response in fish include hematocrit level, leukocyte count and phagocytosis activity. The study is very important to do as a first step for the prevention of stretococciosis disease.

\section{Materials and Methods}

This research was conducted on August 25-September 16, 2017 at Fisheries Laboratory University of Muhammadiyah Malang. Equipment used is Autoclave, Centrifuge, Micropet well, Freezer, Microscope, Micro pipette, Aquarium 20 pieces, Ruler, Pipette, Glass Object, cover glass, Incubator, Aerator, Bucket, Tabbung hematokrit, Haemocytometer, Thermometer, pH pen, DO meter. The materials used for the research are tilapia size 9-12 cm, Streptococcus agalactiae bacteria from BPBAT Sempur Bogor, Wood songga, EDTA, PBS, Giemsa 7\%, BHI, Mikrotube, pellet 22-28\%, Clove oil, $\mathrm{NaCl}$ physiological, Tissue, immersion oil, injection, betadine, Alcohol, Methanol $70 \%$. The research method used is the experimental method using Completely Randomized Design (RAL). This study used 4 treatment 1 control and each treatment was repeated 4 times. The dosage used is: $0 \mathrm{mg} / \mathrm{l}$ (Control), $5 \mathrm{mg} / \mathrm{l}, 10 \mathrm{mg} / \mathrm{l}, 15 \mathrm{mg} / \mathrm{l}, 20 \mathrm{mg} / \mathrm{l}$.

\subsection{Songga Wood Extraction.}

Songga wood powder is macerated with $70 \%$ methanol with a ratio of $1: 3$ for 3 days. Songga wood powder is macerated and then filtered. The maseration results are evaporated in the rotary evaporator at a temperature of $80^{\circ} \mathrm{C}$ in $1800 \mathrm{rpm}$ until the methanol odor is lost. 


\subsection{Blood Sampling.}

Blood sampling was done 3 times ie day 1 (pre-study), day 15 (after treatment) and day 20 (after test challenge). Blood was taken as many as 2 per fish tank.

\subsection{Postulat Test of Tilapia Fish.}

Preparing two aquariums, tilapia is injected with Streptococcus agalactiae bacteria and fed into each aquarium of 2 tails per aquarium, leave for 48-72 hours. If clinical symptoms of $S$. agalactiae attack occur, take the affected part then culture in the BHIA (Brain Heart Infusionion Agar) medium.

\subsection{Challenge Test.}

After giving the wood songga extract to feed for 15 days then it was tested then indigo tilapia injected with $S$. agalactiae $106 \mathrm{cfu} / \mathrm{ml}$ as much as $0,1 \mathrm{ml}$ per head.

\subsection{Calculation of hematocrit level.}

Blood is inserted into a hematocrit tube with a 3: 4 ratio, cover every hole by night, centrifuge a hematocrit tube for 5 minutes at $3000 \mathrm{rpm}$, calculate the length of red blood cells in a hematocrit tube.

\subsection{Calculation of leukocyte cells.}

Blood is sucked with a white grain pipette up to a scale of 0.5 , add Turk solution up to scale 11 , homogenized by swinging for 3-5 minutes, the first two drops are dumped, the solution is dripped into a Neubauer-type haemocytometer with glass cover, count the number of red blood cells by with a 400x magnification microscope, the number of leukocytes in 5 small squares.

\subsection{Test Phagocytosis Activity.}

$50 \mu \mathrm{l}$ of blood is added to the microplate well, add the bacteria $S$. agalactiae 107 cells / $\mathrm{ml}$, mix the solution by pippeting, incubate for 20 minutes, take $5 \mu$ place in the glass object, make the preparation pillow and leave to dry, fixation with absolute methanol for 5 minute and dry air, colored preparations with $7 \%$ giemsa for $10 \mathrm{~min}$, observe under a 1000x magnification microscope with the help of immersion oil, phagocytosis activity is expressed in the number of cells infecting bacterial / 100 cells of phagocytes observed multiplied by $100 \%$.

Parameters observed in this study were three levels of hematocrit, leukocyte count, and phagocytosis index. While the supporting parameters are MIC test and water quality. Data obtained from the observation of the research will be analyzed by analysis of variance (ANAVA), then continued with the test of the Smallest Differences (BNT Test) at 5\% and $1 \%$ level.

\section{Results and Discussion}

\subsection{Hematocrit Level}

In Figure 1. the average graph of the hematocrit level of Bond test tile (1979) states that the normal hematocrit limit of some marine fish species ranges from $42 \%$, in teleostei fish which is around $20-30 \%$. At first blood-taking the hematocrit values of all treatments are within the normal 
range. In the second blood collection decreased the hematocrit level to below $20 \%$ in the treatment of $15 \mathrm{mg} / \mathrm{I}$ and $20 \mathrm{mg} / \mathrm{I}$ which caused the fish in abnormal condition.

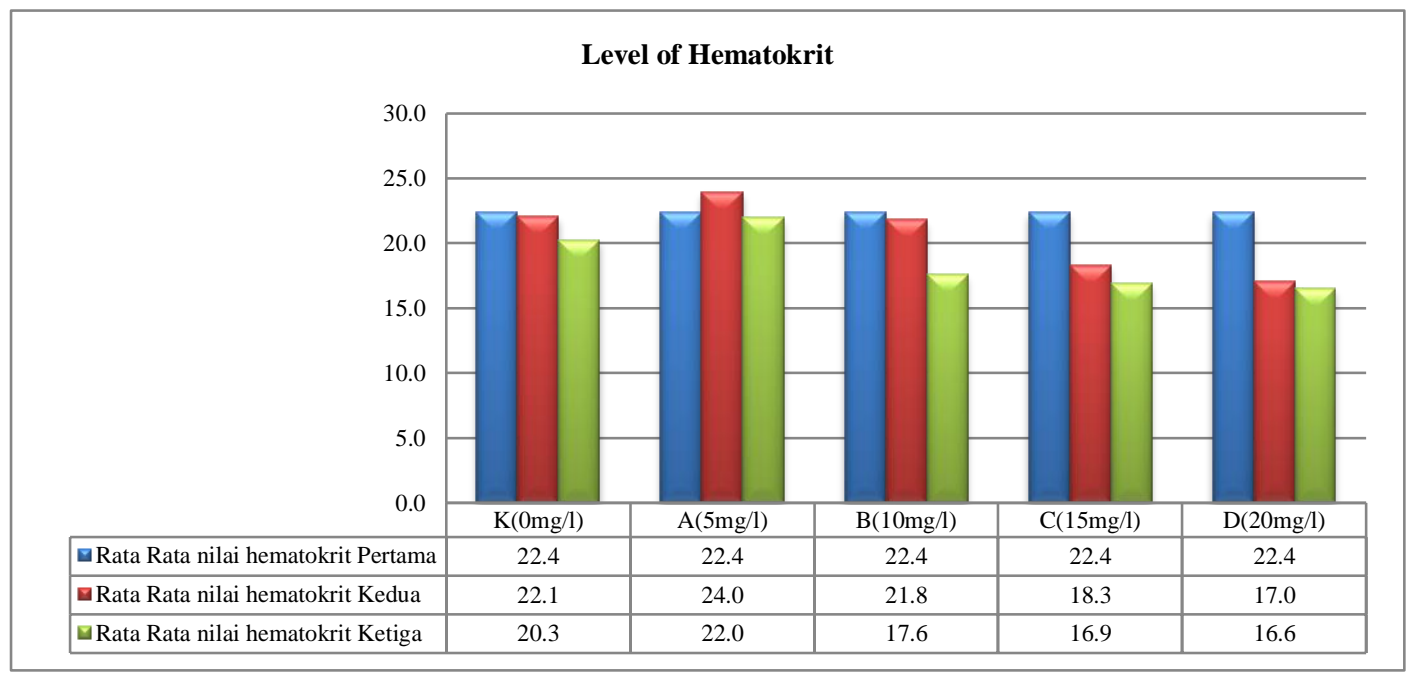

Figure 1. The average graph of hematocrit level of the test tilapia fish

A decrease in hematocrit level also occurs in the third blood taking in all treatments. This proves that the presence of bacterial strains of $S$. agalactiae affects the hematocrit level at the last observation. The results are reinforced by Dellman and Brown (1989) assertion that when infected, the appetite of fish will decrease and the value of blood hematocrit will decrease. The persistent decrease in hematocrit levels occurring from the first to the last blood collection at treatments $\mathrm{C}$ (15\%) and D (20\%) was thought to be due to indications of toxic compounds in the form of saponins with an intolerable amount of tilapia.

According to Alsuhendra and Ridawati (2013) saponin compounds are one of the toxic substances of plant origin, which are secondary to plant metabolites and are toxic to fish, saponins also have surface pressures that can decrease activity, induce foaming, and can menghemolisis red blood cells.

\subsection{Leukocrit Level}

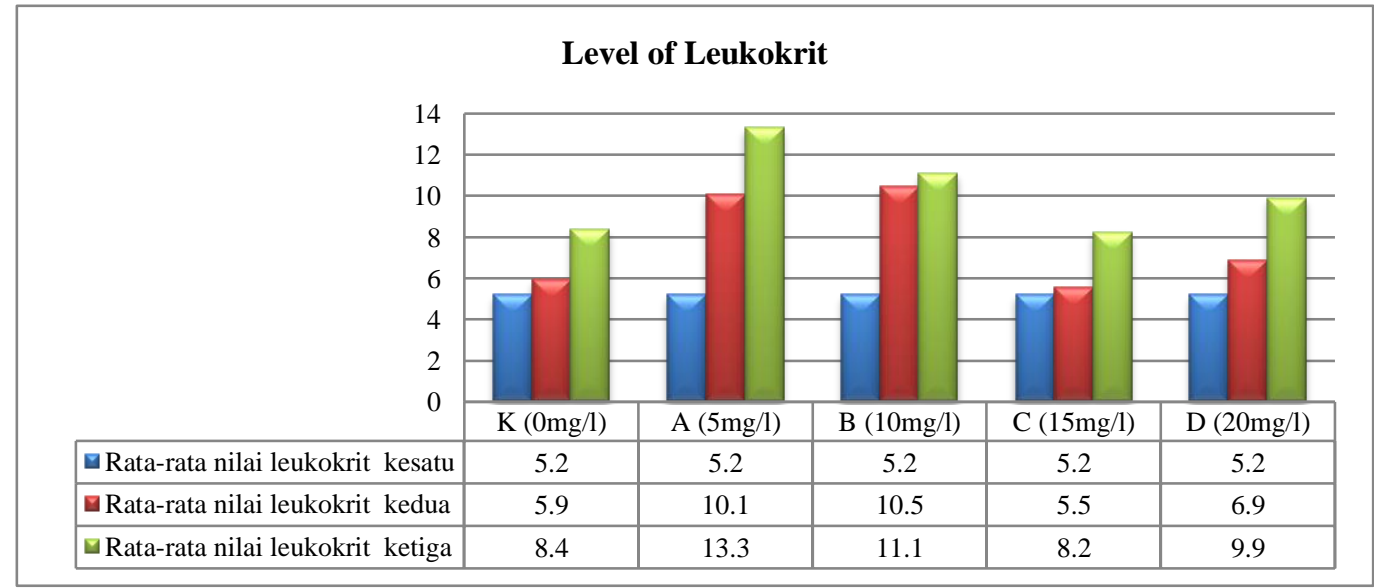

Figure 2. Graph of average leukocrit level of tilapia fish 
In Figure 2. the average graph of leukocrit level of test fish based on Bond statement (1979) that the normal range of tilaprine of tilapia is $4-10 \%$. Therefore the leukocrit value of the first bloodtaking within the normal range. In the second blood collection there was an increase in leukocrit in the control treatment, $5 \mathrm{mg} / \mathrm{l}$ and $10 \mathrm{mg} / \mathrm{l}$. This shows the extract of wood songga give effect on the improvement of tilapia fish immune. However, the decrease in leukocrit levels occurred in the treatment of $15 \%$ and $20 \%$, allegedly this is due to the presence of toxic compounds that are antithyroid which causes the decrease in the amount of oxygen in the blood. Oxygen in the fish body that serves as one of the energy-forming components, to produce more leukocyte cells of course required enormous energy as well and to produce energy then needed enough oxygen. If oxygen is not sufficient to inhibit the formation of leukocyte cells that result in the immune response of tilapia decreased. This statement is reinforced by Alsuhendra and Ridawati (2013) stating that If saponin compounds are hydrolysed with enzymes to produce thiocyanate, isothiocyanate and bensilsianate which are toxic and have antithyroid properties. Antithyroid causes a decrease in thyroid hormones in the body, while the tirois hormone serves to stimulate almost every body tissue to produce proteins and increase the amount of oxygen used by the cell.

Increased levels of leukocrit occur in third blood collection. This is due to early infection of the bacterium Streptococcus agalactiae. Anderson and Siwicki (1994) suggest that low leukocrit may be caused by chronic infection, poor nutritional quality, vitamin deficiency and contaminants. Meanwhile leukocrit increase may indicate early infection or fish under stressful conditions.

\subsection{Number of Leukocytes}

In Figure 3. average graph the number of Tilapia Fish leucocytes shows an increase in the number of leukocytes in each blood collection. At first blood-taking the average number of leukocytes has the same result that is $5.1 \times 105 \mathrm{cells} / \mathrm{mm}^{3}$. In the second blood taking each treatment increased the number of leukocytes. The highest leukocyte count was in treatment B (10\%) ie $11.9 \times 105$ cells $/ \mathrm{mm}^{3}$ and treatment with lowest leukocyte count was found in treatment $\mathrm{D}(20 \%)$ that is $5,6 \times$ $105 \mathrm{cell} / \mathrm{mm}^{3}$. Normal leukocyte counts in fish by Moyle and Cech (2004) are generally fewer than the erythrocytes between 20,000 and $150,000 \mathrm{cells} / \mathrm{mm}^{3}$. The high number of leukocytes in the second blood collection can be caused by the influence of the extract of songga wood as immunostimulant. Phenolic compounds consisting of senol, tannin and flavonoids are anti-bacterial compounds that can inhibit the action of enzymes in bacterial cells. Guenther (1987) states active phenol compounds as antibacterial compounds by mechanisms forming complexes with cell proteins that inhibit the action of enzymes in bacterial cells. As a result the cell wall structure will have protein denaturation. Known in general gram positive cell wall and gram negative bacteria mostly composed of protein.

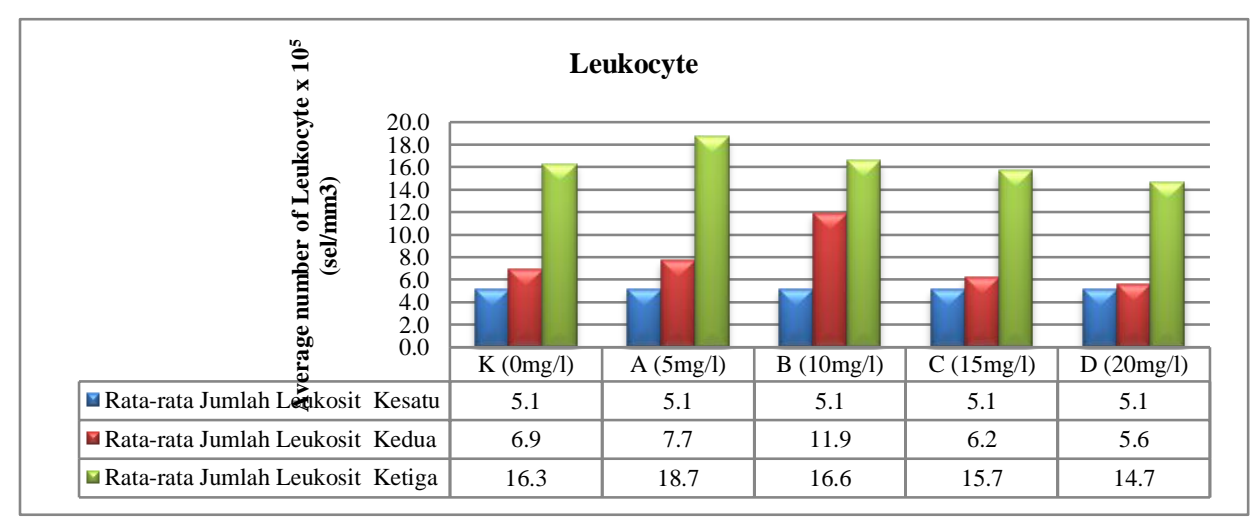

Figure 3. Graph of average number of leukocytes of test Tilapia fish 
The above statement reinforces the observation of the number of leukocytes in the last bloodtaking. At all treatments increased the number of leukocytes after the infection of the bacterium $S$. agalactiae. Anderson and Siwicki (1994) that Leukocrit is a percentage of the number of leukocytes in the blood. low leucocrit may be caused by chronic infection, low nutritional quality, vitamin deficiency and the presence of contaminants. Meanwhile leukocrit increase may indicate early infection or fish under stressful conditions.

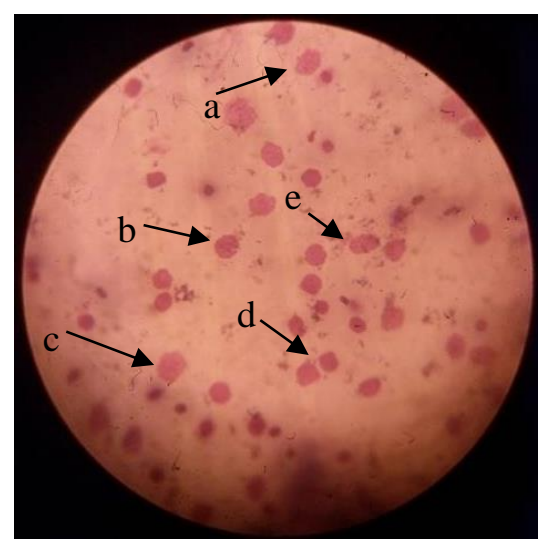

Figure 4. Phagocytosis Cell Activity that Phagocytes Bacteria (Magnification 100X); arrows indicate the activity of phagocytosis (mark a; b; $c$; $d$ is phagocytosis activity, mark $e$ is the bacterium Streptococcus agalactiae)

Figure 4. Phagocytosis activity above shows cells that are phagocytic bacteria $S$. agalactiae. Selected cells by arrows are macrophages surrounded by small points resembling chains, they are S. agalactiae bacteria. The monocyte cell above has an irregular shape, this is in the activity of phagocytosis called the process of destruction. The destruction of bacteria by phagocyte cells is the end of phagocytosis activity so that macrophages appear to be destroyed and irregular. This is in line with the opinion of Abbas et al. (2014) that macrophage phagocytosis has several stages such as chemotaxis (phagocyte movement approaching bacteria), adhesion (ingratitude), ingestion (ingestion), and degranulation (microbial destruction).

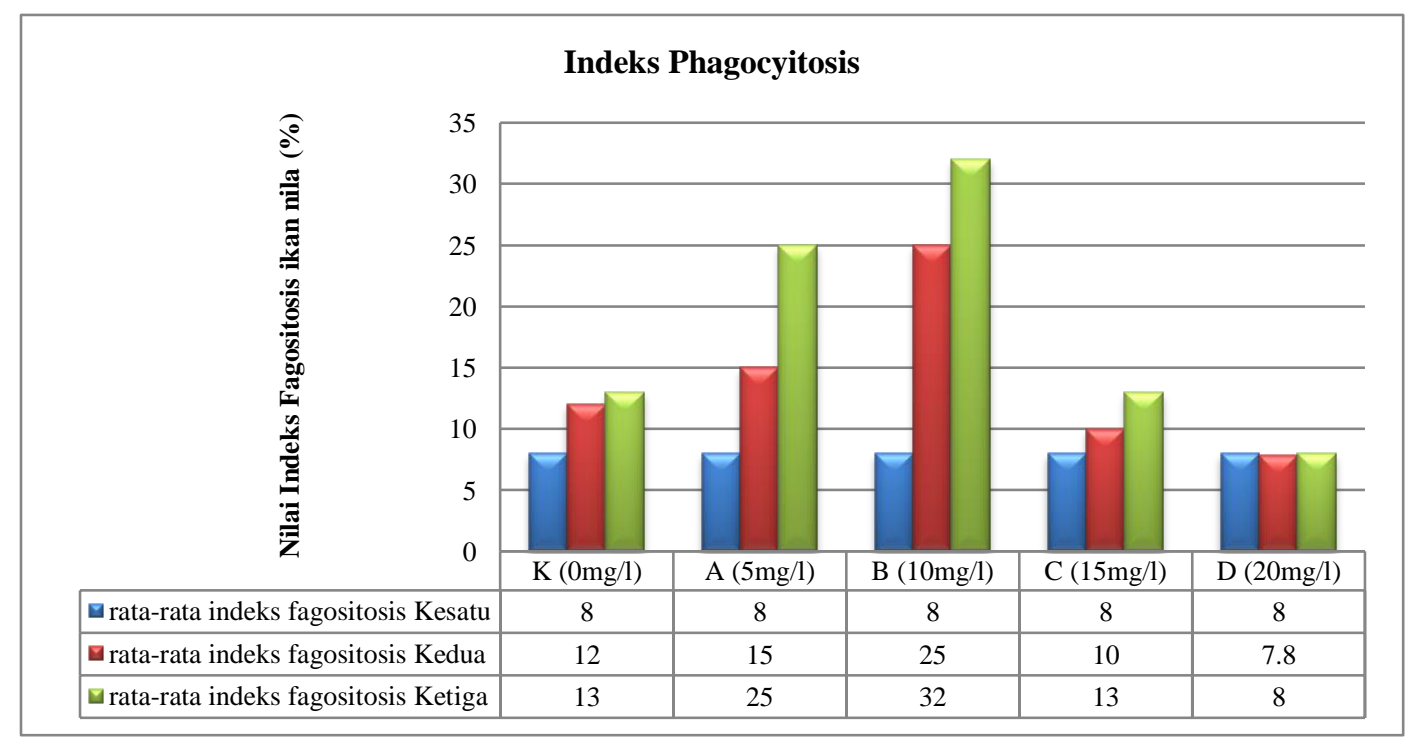

Figure 5. Average graph of phagocytosis index of tilapia fish 
Figure 5. Graph of Average Phagocytosis Index of Tilapia The above test of each treatment has increased and decreased. At the first blood-taking average of the phagocytosis index all treatments were equal to $8 \%$. In the second blood sampling there was an increase of phagocytosis index at all treatments, the highest phagocytic index was found in the treatment of $10 \mathrm{mg} / \mathrm{l}$ of $25 \%$ and the lowest in the treatment of $20 \mathrm{mg} / \mathrm{l}$ of $7.8 \%$. In the third blood taking value of phagocytic index is still highest at $10 \mathrm{mg} / \mathrm{l}$ treatment is $32 \%$ and the phagocytosis index value is $20 \mathrm{mg} / \mathrm{l}$ treatment of $8 \%$.

Increased phagocytosis index experienced during the study was thought to be caused by antibody stimulation of the fish body increased in line with the provision of antimicrobial compounds contained in the songga tree extract. The compound works as immunostimulant against leukocyte cells after tilapia is infected with $S$. agalactiae bacteria. Immunostimulant is a natural or synthetic substance that serves to improve the body's defense system. This result is in line with the opinion of Secombes (1996) who stated that low phagocytic activity may be caused by contaminants, stress, chronic infection and lack of protein and vitamins. While the activity of high phagocytosis is generally caused by the immunostimulant, early vaccination or early response to infection. Fadhilah (2009) states that infections caused by bacteria that enter the body will experience the process of phagocytosis in which phagocyte cells will recognize and digest the particles of bacteria that require oxygen resulting in decreased erythrocytes.

\section{Conclusions}

Treatment of various dosages of songgae extract had significant effect on leukocyte count on second blood sampling (post 2 weeks of songga tree extract) and phagocytosis index of blood sampling of three indigo fish. Doses that provide the highest immune response is on treatment $B$ with a dose of $10 \%$ songga wood extract with leukocyte count $11.9 \times 105$ cells / mm $\mathrm{mm}^{3}$ and phagocytosis index $32 \%$. Based on the results of this study can be suggested to do further research in a longer period of time for the giving of songga tree extracts on tilapia fish to have a more effective effect on the immune response of tilapia fish.

\section{References}

Abbas AK, Lichtman AH, Pillai S. 2014. Basic Immunology, Fourth Edition, Elsevier, Saunders, Philadelphia.

Alsuhendra, Ridawati. 2013. Bahan Toksik dalam Makanan. PT Remaja Rosdakarya : Bandung.

Anderson, Swicki. 1994. Basic Hematolog and Serology for fish health. Program paper presented in second Symposium on disease in Asia Aquaculture Aquatic Animal Health and The Environment Phuket, Thailand. 25-29th October 1993

Bond CE. 1979. Biology of Fishes. Saunders College Publishing. Philadelphia. $514 \mathrm{hlm}$.

Dellmann dan Brown.1989. Buku Teks Histologi Veteriner. Edisi ke-3. Penerjemah: Hartoni, R. judul buku asli: Textbook Of Veterinary Histology. Universitas Indonesia Press. Jakarta: 592598.

Hartoni, R. judul buku asli: Textbook Of Veterinary Histology.,

Universitas Indonesia Press. Jakarta: 592-598.

Fadhilah DN. 2009. Profil Darah Ikan Nila Merah (Oreochromis niloticus) Hibrid yang diinfeksi bakteri Streptococcus agalactiae dengan kepadatan berbeda. FPIK Undip. Semarang. $84 \mathrm{hlm}$.

Guenther E. 1987. Minyak Atsiri jilid I (Terjemahan). Jakarta : UI Press. Hal. 44-484..

Moyle PB, Cech Jr JJ. 2004. Fishes. An Introduction to Ichthyology. $5^{\text {th }}$ ed. USA: Prentice Hall, Inc. 
Sarmento ND, Apilak W, Ratchanok P, Supaluk P, Somsak R, Virapong P. 2015. Antimicrobial, Antioxidant, and Anticancer activities of Strhychnos lucida $R$. Br. http://dx.doi.org/10.4314/ajtcam.v12i4.18.

Secombes CJ. 1996. The Nonspecific Immune System: Cellular Defenses. In: Iwama G, and Nakanishi T (Eds). The Fish Immune System. Academic Press, San Diego. Hal. 63-105. 